\title{
LAW ENFORCEMENT ON TAXATION THROUGH NON LITIGATION MECHANISM (AN ALTERNATIVE)*
}

\author{
Zainal Muttaqin ${ }^{* *}$, Dewi Kania Sugiharti"**, I. Tajudin ${ }^{* * * *}$ \\ Tax Department, Faculty of Law Universitas Padjadjaran, Bandung \\ Jalan Dipati Ukur Nomor 35, Bandung, Jawa Barat 40132
}

\begin{abstract}
The Attorney General can discontinue the investigation to the default tax obligor together with the imposition of four times of outstanding fines. That are raises the issues concerning the nature of the crimes of the tax obligor. This happens because with the payment of the tax debt, the loss suffered by the state as the element of crime, the crimes seemed to be inexistence. This research was an empirical-juridical one. The aim of the research was to find a model of legal enforcement in tax matters without the court involvement.
\end{abstract}

Keywords: tax, investigation, law enforcement.

\section{Intisari}

Jaksa Agung dapat menghentikan penyidikan terhadap wajib pajak apabila wajib pajak tersebut membayar pajak yang terutang beserta denda 4 (empat) kali jumlah pajak yang tidak/kurang dibayar. Hal tersebut menimbulkan persoalan mengenai akibat hukumnya terhadap sifat perbuatan pidana yang dilakukan wajib pajak mengingat dengan pelunasan pajak tersebut, kerugian negara sebagai unsur tindak pidana tidak terjadi. Penelitian ini merupakan penelitian yuridis empiris dengan tujuan menemukan model penegakan hukum di bidang pajak tanpa melalui proses pengadilan.

Kata Kunci: pajak, penyidikan, penegakan hukum.

\section{Pokok Muatan}

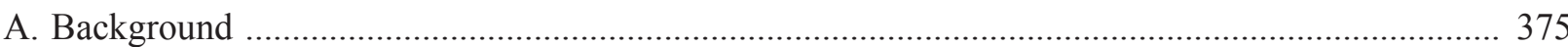

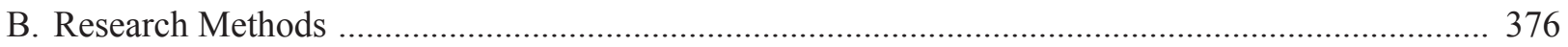

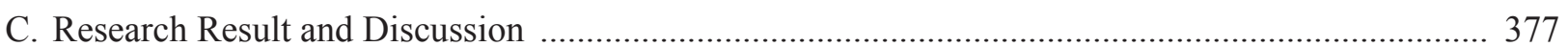

1. Legal Consequences of Tax Payment towards Nature of Criminal Acts .................................... 377

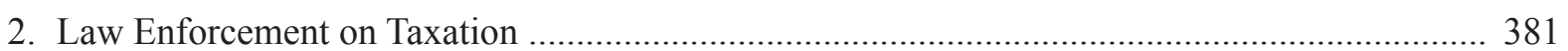

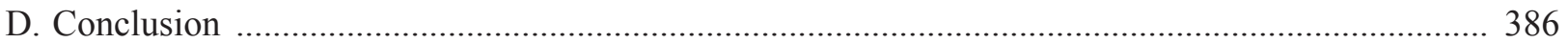

\footnotetext{
Research Result of Faculty of Law Universitas Padjadjaran, 2014

Correspondence address: zm fh76@yahoo.com

*** Correspondence address: dewikaniasugiharti@gmail.com

***** Correspondence address: i.tajudin@yahoo.com
} 


\section{A. Background}

One of the largest source of state revenue in the context of national income is derived from tax sector. As one source of revenue, taxes have an important role in the development process in Indonesia. Tax is one of the capital to realize the independence of a nation in development financing by exploring the domestic resources. In order to realize the independence of this financing required community participation in national development fund to perform its obligations in paying taxes as a source of state revenue.

It is inevitable that tax revenue is one of the biggest national income of Indonesia, since source of tax revenue in the budget in recent years more than $77 \%$ of the whole national incomes. This condition will certainly have an impact on the financial system and national economic system in order to achieve the objectives of the nation that is the social welfare.

Based on the State Budget (APBN), national income from tax sector shows an increase from year to year. It was Rp 619.922 billion in $2009, R p$ $743,325.90$ billion in 2010, USD 839,540.30 billion in 2011, and USD 1,019,332.40 billion in $2012 .{ }^{1}$ Referring to APBN in 2013, the tax revenue target was set at $\mathrm{Rp} 1,193$ trillion, where tax revenue contributed $77.99 \%$ from the whole national income which was set at Rp 1529.7 trillion. ${ }^{2}$ Whereas under the provisions of Law Number 23 of 2013 on State Budget (APBN) 2014, national income from tax sector was targeted at $\mathrm{Rp} 1.280$ trillion or equal to $76.8 \%$ of total national income amounted to $\mathrm{Rp}$ 1,667 trillion.

In the existing taxation system, based on the Law Number 6 of 1983 concerning Taxation General Provisions and Procedures as last amended by Law Number 16 of 2009 (hereinafter Taxation General Provisions and Procedures Law), people are given full credence to calculate, determine and pay the tax due (self-assessment). Exercising their rights and obligations is left entirely to the taxpayer, while the tax authorities/tax administration only serves to provide guidance, supervision/inspection and sanctions (administrative), either in the form of fines, interest and hikes. Authority to impose criminal sanctions such as fines and imprisonment/ confinement remains on the court.

Considering the nature of the tax payment which has no consideration that might be obtained by the taxpayer, then there is a tendency for people to avoid tax paymeny. Although the tax sector revenue is increasing every year, but looking at the numbers of tax ratio and tax coverage ratio was still low compared to another countries of ASEAN.

For instance, "tax coverage ratio" Indonesia stands at $50-60 \%$, meaning of potential that shall pay taxes, while approximately $40-50 \%$ do not pay taxes. From $50-60 \%$ of taxpayers actually are not fully fulfil their obligations properly as has been regulated by the law. It consequently harm the financial of the state so that the people are potentially subject to criminal sanctions.

Taxation General Provisions and Procedures Law has set the criminal acts committed by the taxpayer, tax authorities and third parties in Article 38 to Article 43. Especially for taxpayers, the criminal sanctions has been set under Article 38 and Article 39. Generally, a criminal act by the taxpayer is punishable with regard to an action related to the Tax Return, abuse of Taxpayer Identification Number (Nomor Pokok Wajib Pajak, hereinafter NPWP), delivery of incorrect data, not paying the tax, and does not pay taxes. ${ }^{3}$ Although so far there has been no definitive data how many taxpayers are processed to court for committing criminal acts in the field of taxation. However, based on the adage approach that says everyone has a tendency to avoid the tax, it will be a lot of taxpayer exposed to criminal sanctions as set forth under Article 38 and

Ditjen Pajak, "Penerimaan Negara 2009-2012”, http://www.pajak.go.id/content/penerimaan-negara-detil-2009-2012, accessed on 25 March 2014.

Yudhi Mahatma, "Menkeu Optimistis Target Penerimaan Pajak 2013 Tercapai", http://www.republika.co.id, accessed on 25 March 2014. Rochmat Soemitro, 1993, Asas dan Dasar Perpajakan 3, Eresco, Bandung, p. 22. See Suparman, 1994, Tindak Pidana di Bidang Perpajakan, Citra Aditya Bakti, Bandung, p. 78. 
Article 39 Law Number 16 of 2009.

One thing should be considered is the case of tax evasion in PT Ramayana which was performed by Paul Tumewu as the company director. The investigation had been declared complete (P21) and was already in the hands of the prosecutor, then distributed to the court. The investigation was caused by suspected of violation by Paulus that set forth under Article 39 paragraph (1) letter b and c Law Number 16 of 2009, with a penalty of imprisonment of 6 (six) years and a maximum fine of four (4) times of the tax payable amount. However, by using a legal basis Article 44B of Law Number 16 of 2009, the investigation towards Paul was stopped and he was released after paying off taxes along with fines of Rp 40 billion.

According to Article 44B Taxation General Provisions and Procedures Law, for the sake of state revenue, the Attorney General, based on the request of the Minister of Finance may terminate an investigation when the taxpayer has paid tax payable or underpaid tax along with administrative sanctions such as fines amounting to 4 (four) times of amount of the tax payable. However, based on the provision in Article 44B Taxation General Provisions and Procedures Law and its application in cases of tax evasion as a crime was interesting to study, considering to:

First, the tax due along with the fines payment by offenders cause no loss of the state revenue, as has been set as an element of Article 39 paragraph (1). In Article 44B Taxation General Provisions and Procedures Law, there is no formula or statement found regarding the tax payment due to the nature of the unlawful act of the subject..

Second, according to Article 44 and paragraph (1) Taxation General Provisions and Procedures Law termination of the investigation by the Attorney General conducted based on the request of the Minister of Finance by the reason for the sake of the state. Thus, the Attorney General cannot stop the investigation by their own initiative, without the request of the Minister of Finance. The problem that arises, whether the Attorney General may refuse a request termination of the investigation of the Ministry of Finance.

Third, in the criminal law principle known as "ultimum remedium", i.e. criminal sanctions are a last resort when other sanctions are not effective enough to combat crime. If this principle is connected with the case above, whether Article 44B Taxation General Provisions and Procedures Law is an implementation of the ultimum remedium principle, so that against a criminal case through the tax administration law enforcement does not need to go through the court process. If this concept is implemented, the problem then is about the existence of criminal sanctions itself in law enforcement in the field of taxation.

However, it has not been known whether how many termination of the investigation of criminal tax using the legal basis of Article 44B Taxation General Provisions and Procedures Law. Then, whether the tax due payment along with the fine payment as well as the case above can be used as a model of law enforcement in field of taxation, without being processed through the litigation.

Finally, based on the previous explanation so that it concludes some legal problems to be answered in this research as following: First, whether the payment of tax due along with administrative fines as has been set forth under Article 44B Taxation General Provisions and Procedures Law causes abolishment of the taxpayer's criminal acts?; and Second, whether the payment of tax due along with administrative fines as has been set forth under Article 44B Taxation General Provisions and Procedures Law can be used as a model in the field of tax law enforcement?

\section{B. Research Methods}

Research on law enforcement in the field of taxation through non litigation mechanism is kind of juridical-empirical research. Juridical research is intended as a normative legal research, which is perceived as the norm or rule of law. This research analyses the provision of Article 44B of Law Number 28 of 2007 on Taxation General Provisions 
and Procedures, the Criminal Code, and the Criminal Procedure Code. While the empirical legal research conducted on the implementation of norms or rules that are the object of research, namely Article 44B of Law Number 28 of 2007 associated with the Criminal Code and the Criminal Procedure Code.

The primary data from field research were obtained through interview towards experts who have relevance competence to issue of this research i.e. the Directorate General of Taxation, Ministry of Finance of the Republic of Indonesia and the Attorney General of the Republic of Indonesia. Then, collected data that was obtained from interview sorted by variables contained in this research problems. Furthermore, the data were analysed based on qualitative methods. In case that some figures were not meant to be analysed quantitatively but only to sharpen the research problems.

The secondary data in this normative research covers materials primary law, secondary law, and tertiary legal materials obtained through library. The primary legal materials are preferred Law Number 28 of 2007, the Criminal Code, and the Criminal Procedure Code, whereas secondary law such as the papers of experts in the field of tax law and criminal law.

\section{Research Result and Discussion}

1. Legal Consequences of Tax Payment towards Nature of Criminal Acts

a. Termination of Crime Investigation

As has been explained in the background, the crime of in field of taxation is not just set in the Taxation General Provisions and Procedures Law, but also regulated under the Law of Land and Building Tax (Pajak Bumi dan Bangunan), Law of Stamp Duty (Bea Materai), and so on. Thus, crime acts referred to Article 44B Taxation General Provisions and Procedures Law is not limited to tax crime that set out in the Law a quo, in particular Article 38 and Article 39. In other words, crime in field of taxation that is not regulated under the Taxation General Provisions and Procedures Law, so that the investigation may be terminated under Article 44B Taxation General Provisions and Procedures Law. In this case for a criminal offenses except the tax crime, based on the provisions of Article 109 paragraph (2) Criminal Procedure Code, termination of the investigation in a limited manner can only be done if there is no sufficient evidence, where the incident is not a crime, termination by law (because of nebis in idem, a suspect dead, or expiration date). Termination of investigation in the Taxation General Provisions and Procedures Law set out in Article 44A, namely there is no sufficient evidence, the incident is not classified as a crime, the suspect dead, and the expired case. Thus, the termination of investigation regulated in the Article 44B Taxation General Provisions and Procedures Law is a kind of lex specialis of Article 44A Taxation General Provisions and Procedures Law and the Criminal Procedure Code.

Investigation of criminal acts which are set forth under Article 38 and Article 39 Taxation General Provisions and Procedures Law can be terminated regarding to the Article 44B Taxation General Provisions and Procedures Law, among others, by submitting an incorrect or incomplete notification letter or do not submit the notification letter. Thus, causing losses to the state revenue. Criminal act as referred to is a purely criminal act which administratively punishable with criminal sanctions. Criminal acts in the field of taxation that contain criminal elements common as using false or forged documents, create invoices by any party who has no authority on it or using fake tax invoices, cannot use the termination of the investigation that set forth under Article 44B Taxation General Provisions and Procedures Law. Similarly, it can be the same treatment 
for cases concerning other crimes such as corruption, wiping and so on.

Termination of criminal investigations under Article 44B Taxation General Provisions and Procedures Law only applies to criminal acts committed by the taxpayer, or in other words, the criminal is the taxpayer. Thus, the criminal acts set out in Taxation General Provisions and Procedures Law, which is carried out by the tax authorities/ tax employees and third parties cannot be terminated pursuant to Article 44B Taxation General Provisions and Procedures Law. For example, officials/employees who do not meet obligations to keep secret as the provision of Article 34 Taxation General Provisions and Procedures Law, so that the investigation will be continued as long as it doesn't comply with the provisions of Article 109 paragraph (2) Criminal Procedure Code. Similarly, for example, someone who makes a tax invoice or a fake tax invoice while actually the person does not have the authority to create a tax invoice or a Non-Taxable Entrepreneur (Pengusaha Kena Pajak). Investigation and prosecution towards criminal offenses committed by non-taxpayers will be continued. In case to employee and third party where investigation of the cases are terminated, so that the legal basis of those cases is not the Article 44B Taxation General Provisions and Procedures Law, but Article 109 paragraph (2) Criminal Procedure Code.

\section{b. Consideration of Termination of In- vestigation}

Taxpayers should submit their application concerning termination of the investigation to the Minister of Finance Application, then the Minister will forward the application of taxpayers to the Attorney General. Request for termination of the investigation by the taxpayers to the Minister of Finance must meet the following requirements:

1) application shall be in writing;

2) pay off the entire underpayment tax along with the administrative fines based on the results of the tax authorities;

3) admitting mistakes or errors in filling the Tax Return; and

4) attach proof of tax payment.

In practice, after the verification of the tax payment validity, Ministry of Finance, in principle, grants the request of the taxpayer to be used as a reason to apply for termination of the investigation to the Attorney General. Minister of Finance will not consider the minimal amount of tax due that will be granted or denied. Throughout the tax due and the administrative fines are paid according to the examination results so that the taxpayer's application shall be granted.

Although the provision of Article 44B Taxation General Provisions and Procedures Law using the word "may"4, but generally, from all applications requested by the Ministry of Finance, the Attorney General would grant the application by considering the condition that, throughout the criminal case by the taxpayer has not been transferred to the court and does not contain elements of another criminal act, such as corruption, money laundry and so on.

Therefore, all taxpayers who pay off the tax due and the administrative fines as required by Article 44B Taxation General Provisions and Procedures Law, the request will always be granted. According to data from the Tax Directorate there are 20 (twenty) people who have been granted the petition, while the data obtained from the Attorney General from 2010 through 2014 as many as 9 (nine) people were given taxpayer 
assessments termination of investigation (SKPP) with the value of a state income from tax sector amounted to Rp 153. 159021925 , consisting of:

Table 1. Number of Taxpayers with Termination of Investigation Based on Termination of Investigation Letter (SKPP) along with the Tax Due and Fines Payment as A Result of Discontinued Investigation in 2010-2014

\begin{tabular}{ccl}
\hline Year & $\begin{array}{c}\text { Amount of } \\
\text { SKPP }\end{array}$ & \multicolumn{1}{c}{ Value } \\
\hline 2010 & 2 & $\operatorname{Rp~100.977.716.815~}$ \\
2011 & 2 & $\operatorname{Rp~} 6.251 .963 .250$ \\
2012 & 1 & $\operatorname{Rp~10.921.156.805~}$ \\
2013 & 2 & $\operatorname{Rp~25.291.741.490~}$ \\
2014 & 2 & $\operatorname{Rp~9.725.443.565~}$ \\
\hline Total & 9 & $\operatorname{Rp~153.159.021.925~}$ \\
\hline
\end{tabular}

Source: Interview with Head of Sub Directorate TPKL, Execution and Examination of the Attorney General, September 23, 2014.

There was a difference data found between the Directorate General of Taxation with the Attorney General, namely 11 (eleven) taxpayers. Of total 11 (eleven) taxpayers were partially cancel the request or did not fulfil their obligations to pay the tax due and fines. Against the taxpayers, it would be continued the criminal investigation process. Some of them were made possible in the submission process from the Minister of Finance to the Attorney General.

Either acceptance or rejection of the request by the Minister of Finance and the termination of the investigation by the Attorney General is not determined by the amount of the nominal of the tax due, but is determined by the good faith of the taxpayer, cooperative, error recognition, and both of the tax and fines repayment.

According to Romli Atmasasmita, ${ }^{5}$ two paragraphs of Article 44B Taxation General Provisions and Procedures Law clearly shows that the political direction of Indonesian tax law adheres to the "dual-track policy". On the one hand aims to enforce discipline confirm that taxes as one of the main source of national income, while on the other hand use a "sunrise policy" with the aim of optimizing the national income. Judging from the system of separation of powers, the provisions of Article 44B Taxation General Provisions and Procedures Law can be a form of executive intervention of the judicial power. However, from the standpoint of economic analysis approaches, such provision is one of the efficient ways to support the national economy.

This amount is considered still quite small if seeing the digit tax ratio and tax coverage above. But, this is understandable considering the case in the field of criminal tax must go through the process of examination by the Directorate General of Taxation in case there is indication of criminal offense in the field of taxation. Furthermore, it will be continued to the investigation process. Meanwhile, given the limitations of tax inspectors, to all taxpayers have not been examined. In accordance with the Minister of Finance Regulation No. 199/ PMK.03/2007 as last amended by Minister of Finance Regulation No. 82/PMK.03/2011 on Examination Procedures, examination will be held against the taxpayers who:

1) submit the Tax Return which is overpayment;

2) apply for a refund of excess tax payments;

3) submit Tax Return which is stated loss;

4) undertake a merger, consolidation, expansion, liquidation or will leave Indonesia forever;

5) making changes in the book year; 
6) neither submit the Tax Return nor submit the Tax Return, but beyond the period stipulated in the warning letter;

7) filed an objection; and

8) Taxpayer Identification Number (Nomor Pokok Wajib Pajak, hereinafter NPWP) deletion, and so on.

\section{c. Nature of Criminal Acts after Tax Repayment}

In context criminal law, it is known a doctrine concerning against the law of nature, that is against the law both of in the context of formal and material law. Nature of an act against the law in the formal sense says that when an act has met all of the elements contained in the formulation of criminal acts, such actions is identified as a criminal act. If there are justifiable reasons, then the reasons should also be mentioned explicitly in laws. ${ }^{6}$ Whereas nature of an act against the law in the material sense says that besides fulfil formal requirements, that meet all of the elements listed in the formulation of the offense, the act must actually felt by public as an act of improper or disgraceful. Hence, this doctrine acknowledges the justifiable reasons that is not written in the law. In other words, the justification may be the unwritten law. ${ }^{7}$

In the criminal law, position of nature of an act against the law may be a very distinctive nature. Andi Zainal Abidin said that one of the essential elements of the offense is the nature of an act against the law (wederrechtelijkheid) which expressly states or not written in an article of criminal law. This may be odd if someone is liable by the reason that actually the acts are not identified as an act against the law. ${ }^{8}$ While Ruslan Saleh said, criminalize something that is not against the law means nothing. ${ }^{9}$ The words against the law sometimes expressly and explicitly formulated in the formulation of offense and sometimes not expressly and implicitly formulated. If an act against the law is formulated expressly and explicitly included in the formulation of the offense, so it becomes significance to provide protection or give guarantees for the person to be not convicted by the authorized person to do several actions as defined in the legislations. ${ }^{10}$

As consequences of inclusion of an act against the law in the formulation of the offense causes obligation of the prosecutors so that they have to prove these elements. Meanwhile, if the element of an act against the law is not mentioned or referred to expressly and explicitly in the formulation of the offense, then these elements do not need to be proven, the element of against the law is automatically proven when the prosecutors prove the prohibited actions. ${ }^{11}$

The nature of an act against the law may erase in case there is justification of the action did. Those reasons can be something that abolish criminal acts by justifying the acts. Justification is the reason that erase action against the law nature of what was done so that the accused then could be justified as appropriate actions. ${ }^{12}$ Theoretically, something that can be categorized as a justification of the criminal law namely forced defence, to implement the provisions of the law and carry out the orders of the higher rank officers (commands). While an excuse or faitd'excuse may because there are

Komariah Emong Sapardjaja, 2013, Ajaran Sifat Melawan Hukum Materiil dalam Hukum Pidana Indonesia: Studi Kasus tentang Penerapan dan Perkembangannya dalam Yurisprudensi, Alumni, Bandung, p. 25.

Ibid.

Andi Zaenal Abiding Farid, 2007, Hukum Pidana I, Sinar Grafika, Jakarta, p. 47.

Roeslan Saleh, 1987, Sifat Melawan Hukum dari Perbuatan Pidana, Aksara Baru, Jakarta, p. 1.

Mahrus Ali, 2011, Dasar-Dasar Hukum Pidana, Sinar Grafika, Jakarta, p. 144.

Tongat, 2008, Dasar-Dasar Hukum Pidana Indonesia dalam Persfektif Pembaharuan, UMM Press, Malang, p. 214.

Moeljatno, 2008, Asas-Asas Hukum Pidana, Rineka Cipta, Jakarta, p. 148. 
specific things that make the offender cannot be responsible as Article 44 paragraph (1) of the Criminal Code, a force, a transcend forced defence, and execution of commands without authority that are based on good faith. Thus, in case the criminal acts in the field of taxation, which has been clearly set out in Article 38 and 39 of Taxation General Provisions and Procedures Law about crimes in taxation.

In the investigation of tax crime, there is a provision such as in Article 44 paragraph (1) of the Taxation General Provisions and Procedures Law, that based on the request of the Minister of Finance, the Attorney General may terminate investigations in the field of taxation within a period of 6 (six) months maximum from the date of the request. Minister of Finance's request to the Attorney General about the termination of the investigation towards a tax crime due to the taxpayer paying off the tax due which is unpaid or less paid or that should not be returned and along with administrative sanctions such as fines amounting to 4 (four) times the amount of tax, or that should not be returned in accordance with the Article 44B paragraph (2) of the Taxation General Provisions and Procedures Law. Termination of the investigation by the Attorney General for the sake of national income. The existence of a request from the taxpayers to fulfil their obligation of tax payment along with penalties that accompanied the error recognition, taxpayers apology for their actions as included in the scope of the actions set out in Article 38 or Article 39 of the Taxation General Provisions and Procedures Law. It cannot be a justification to the taxpayers who committed a tax crimes, so it means that the taxpayers' acts still been considered to meet the elements in the field of tax crime.

The tax due payment along with penalties that is 4 (four) times of the amount of unpaid taxes or underpayment taxes do not eliminate the unlawful nature of the taxpayer. Acts committed by the taxpayers still recognized as as an act that is against the law. It means that the taxpayer acts remain categorized as acts contrary to the law referred to the Law Number 28 of 2007 on Taxation General Provisions and Procedures Law. However, Taxation General Provisions and Procedures Law doesn't mention the repayment of the tax due and its penalties that is 4 (four) times of the amount of tax underpayment or unpaid tax may eliminate the unlawful nature of the taxpayer (as a justification). Furthermore, it cannot be recognized as well as the justification as stipulated in the Criminal Code.

In other words, it cannot be said as a justification for the taxpayer or the taxpayer's actions which is not categorized as a justifiable acts. Payment of the tax due along with its administrative sanctions (fines) as defined in Article 44B Taxation General Provisions and Procedures Law doesn't lead to the abolishment of taxpayer's criminal acts. As for the status of the taxpayer before publishing termination of investigation letter (SKPP) remains recognized as a suspect. However, after examining the termination of the investigation request of the Minister of Finance, then the Attorney General grants the request of the Minister of Finance to terminate the investigation process by issuing a termination of investigation letter. The termination of the investigation from the Attorney General towards tax crimes investigations cause the investigation of those cases of tax stop.

2. Law Enforcement on Taxation

\section{a. Law Enforcement Through Administrative Sanctions}

Administrative sanction that is imposed on taxpayers as the implementation of law enforcement in the field of taxation can 
be in form of fines, interest, and tax-increase. The imposition of administrative sanctions to taxpayer as a result of violation of laws and regulations that are naturally administrative. While the imposition of fine, interest, or tax-increase imposed is in accordance with the quality of the violations set forth in the Taxation General Provisions and Procedures Law, such as late submission of Tax Return (Surat Pemberitahuan (Pajak) or SPT), Tax Return self-correcting that may result a greater tax due, underpaid tax as a result of the disclosure of untruth information on Tax Return, late payment of tax due (beyond the due date), and so on.

Authority to impose administration sanctions under the officials (tax authorities/ fiscus) which is authorized given by the Law (in this case, Taxation General Provisions and Procedures Law), without going through a judicial mechanism (based on the court verdict). This is in accordance with the principle of the rule of law in the State Administration Law, which is done by the state administration itself. In addition to administrative sanctions such as fines, interest, and tax-increase, in tax law recognizes sanctions in another form, namely foreclosure, auction, and hostages as stipulated in Law Number 19 of 2000 concerning Tax Collection by Giving Forced Letter.

In accordance with Article 18 paragraph (1) Taxation General Provisions and Procedures Law, Tax Collection by Giving Forced Letter should be preceded by the publication of Tax Collection Letter (Surat Tagihan Pajak), Underpaid Tax Assessment Letter/Additional Underpaid Tax Assessment Letter (Surat Ketetapan Pajak Kurang Bayar/ Tambahan), the Decree of Correction, Decree Objection, Judgment Appeal.

According to the Law Number 19 of 2000 concerning Tax Collection by Giving
Forced Letter, tax collection by giving a forced letter will be made in case:

1) the taxpayers do not fulfil the obligation to pay the tax due even they have been given a letter of reprimand or a warning letter;

2) there has been a collection instantaneously and simultaneously

3) do not meet the requirements as stated in the decision of approval of the installment or delay in payment.

Confiscation and auction in taxes are directly without going through the courts because the Law Number 19 of 2000 gives the title executorial towards a distress warrant which has the same legitimation as the court verdict that has been fixed (incrahtvangewijsde). If within a period of 2 (two) of 24 hours after delivering the distress warrant, but the taxpayers do not pay the tax due as specified in the distress warrant, then there will be a properties/goods confiscation against the taxpayers, either movable or immovable which value is proportional to the amount of tax due to be paid. If within 14 (fourteen) days the taxpayers haven't paid off the tax due, then the confiscated property would be auctioned and if there are still remaining properties/goods then the rest will be returned to the taxpayers.

There will be a hostage (gijzeling) in case there is no property that can be confiscated. The requirements of hostage cover:

1) tax due with minimum nominal amounted to $100,000,000$, -;

2) doubt of taxpayers' good faith;

3) there must be a permit from the Ministry of Finance in context of taxes in national level and the Governor for regional taxes. 
Hostage period is determined of no longer than 6 months and can be extended for 6 (six) months maximum. Law concerning Tax Collection by Giving Forced Letter stipulates that even if the hostage had expired, the tax due remains. In positive law, the term "gijzeling" is not a new terminology because it has been known in the laws and regulations of the Dutch colonial heritage, under Article 209 to Article 224 RIB/HIR and Article 242 to Article $258 \mathrm{RBg}$. Gijzeling which is interpreted as hostages raises the pros and cons among the public and even among legal experts, especially since the emergence of consciousness and human rights issues.

Those opposed argued that gijzeling is a crime against human freedom. Therefore, the Supreme Court of the Republic of Indonesia had issued a Circular Letter of the Supreme Court of the Republic of Indonesia (Surat Edaran Mahkamah Agung, hereinafter SEMA) Number 2 of 1964 and SEMA Number 4 of 1975 , that both of the regulations instruct not to use the rules of the hostage referred to Article 209-224 HIR as opposed to humanity. Hostages considered a deprivation of a person's freedom. But through Regulation of the Supreme Court of the Republic of Indonesia (Peraturan Mahkamah Agung, hereinafter PerMA) Number 1 of 2000, the presence of hostages revived by the Supreme Court with the term of "paksa badan". Article 6 PerMA a quo mentions that the regulation of "paksa badan" set together with the principal case verdict against debtors who have no good faith while they have debts to the state or guaranteed by the state and carried out immediately. Implementation of the decisions concerning the implementation of "paksa badan" shall be based on decision of the chairman of the District Court.

As given by PerMA Number 1 of
2000, in the preamble "in view of" refers to Article 209-224 HIR, need to be quoted by the provision of Article 209 paragraph (1) HIR that seems similar as Article 242 paragraph (1) RBg, as follows: "If there is no or not enough goods/properties to execute judgment (court decision), the obligator (schuldenaer or the debtor) can conduct a hostage" ${ }^{13}$. Based on this provision. Hostages including the scope of execution can only be based after the court decision.

Noticing SEMA Number 2 of 1964 and SEMA Number 4 of 1975, the Supreme Court persuade not to use the hostages only applied for a civil debt, while on the public debt was not regulated. Thus, by implementing analysis of argumentum a contario, hostage due to tax due (public) does not apply SEMA Number 2 of 1964 and SEMA Number 4 of 1975. Therefore, hostage of the tax due is recognized as stipulated in Law Number 19 of 1959 which was later replaced by Law Number 19 of 1997 jo. Law Number 19 of 2000 .

\section{b. Law Enforcement Through Criminal Sanctions}

Law enforcement through litigation or court as a repressive law enforcement, namely an attempt eradication when a criminal act has been carried out. Target of criminal enforcement action aimed at the perpetrators, namely the form of the punishment inflicted by the decision of judge. Thus, the criminal sanctions in Taxation General Provisions and Procedures Law such as imprisonment/ confinement and fines are part of the enforcement of criminal law as a prevention efforts in the field of tax crimes.

Based on interviews with the Directorate General of Taxes and the Attorney General, criminal law enforcement by applying the rules of criminal law in the 
form of criminal sanctions is still needed. Enforcement of criminal sanctions directed against the person who committed the crime were not only violating the rules of administrative law, but also violated the rules of criminal law. Take for instance, falsification of documents, books, records that do not reflect the actual circumstances, resulting in loss of national income as stipulated in Article 39 paragraph (1) Taxation General Provisions and Procedures Law. Falsification of documents is also regulated in Article 263 of the Criminal Code which is a general crime. In terms of counterfeiting, there is a purpose to use a letter/document as that is genuine or not fake that caused losses to the state. Moreover, those acts can also be categorized as misuse or use without authority of NPWP.

In addition to the counterfeiting such above, another things that can be used to assess of the application of criminal sanctions such as the element of intent. It means that the act was committed with a conscious and has a specific purpose. This may become an important factor in assessing the intentional elements, whereas intention always begins with a plan to do something (crime) which are already considering the risk or consequences of the act that is committed.

\section{c. Alternative Criminal Law Enforcement on Taxation}

Law enforcement through nonlitigation mechanism is intended as a law enforcement without judicial mechanism. Based on the criminal justice system, criminal law enforcement starting with the inquiry, investigation, prosecution, investigation in legal proceedings and execution/implementation of the judge's decision (which has been fixed).

Whether Article 44B Taxation General Provisions and Procedures Law can be categorized as criminal law enforcement through non-litigation process? It is necessary to find the elements of Article 44B then applied to the definition of law enforcement (through the courts) itself.

Noticing the provision of Article 44B Taxation General Provisions and Procedures Law, it can be concluded the following elements: Firstly, the existence of a request SP3 by the Minister of Finance to the Attorney General; Secondly, the taxpayer has their paid tax due and fines by 4 (four) times amount of unpaid tax or underpaid tax; Thirdly, only applies to the taxpayer, does not apply to third parties; and Fourth, the case has not been sent to trial.

Request for termination of the investigation should be carried out by the Ministry of Finance to the Attorney General. Taxpayer cannot apply directly to the Attorney General's request SP3, but rather to the Minister of Finance, and the Ministry of Finance will consider the taxpayer's application on whether the request is granted. The Minister of Finance will examine the requirements in the form of a tax due repayment along with fines, assessments of taxpayer's good faith, and also for the sake of national income. Although taxpayer has paid tax due and the fine, but if the Minister of Finance refused, so that towards the SP3 petition to the Attorney General will not be delivered and the case will proceed to court.

Based on interview to the Attorney General, every case concerning termination of the investigation which is requested by Minister of Finance and submitted to the Attorney General would be granted as long as the taxpayer is not involved in other crimes such as corruption, money laundering and so on. In case of criminal offenses that are requested SP3 by the Minister of Finance, there are other elements of crimes (that is not purely a tax crime), so that the application for termination of the investigation will be rejected and the case will be transferred to 
the court.

Taxation laws embraced a selfassessment system which gives full credence to the taxpayer to calculate, set, and deposit the tax due by their selves. Thus, this suggest that the tax authorities give authority to the taxpayer, so that taxpayer reports regarding their taxes should be justified by the tax authorities. The presumption of innocence principle will be implemented towards taxpayer to fulfil their rights and obligations as has been set forth in the legislations along yet proven otherwise.

Thus, the examination as an instrument to assess the validity of the taxpayer's report is needed in case here are indications of taxpayer who does not fulfil the rights and tax obligations properly. Based on the results of this examination will be known whether the report concerning amount of the tax due, underpaid tax, or the unpaid tax is correct or incorrect. Moreover, it will also be known whether there is an indication of taxpayer committing an offense/crime or not. In case there is an indication of taxpayer committing a crime, then there is authority to conduct inquiry and investigation carried out not by the inspectors but by civil servant investigators (PPNS).

Referring to the definition of criminal law enforcement, since the case is handled by the investigators, then this has entered the realm of law enforcement through the litigation mechanism. As a consequence of that, it will go through various steps start from inquiry, investigation, prosecution, trial examination until the court verdict is inkrachtvangewijisde.

This mechanism or procedure will obviously take a long time because there is no time restriction when or how long a case to be settled until the court verdict issued.
Opportunities of criminal law enforcement in the field of taxation without trial is still open as long as criminal acts committed by the taxpayer is identified as purely tax crime, with the following considerations:

Tax crime is basically an act that violates the provisions of administrative law that given criminal sanctions. In accordance with the opinion of Wirjono Pradjodikoro, ${ }^{14}$ the former chief of the Supreme Court of the Republic of Indonesia, a violation of the norms of civil law settled by the rules of civil law, a violation towards the norms of administrative law shall be solved by using the rules of administrative law. This is in line with the ultimum remedium principle, where criminal sanctions are a last resort when other sanctions cannot be implemented.

Thus, as long as taxpayer committing violation towards the norms of administrative law that causes losses to the state, it can be applied to the instrument of sanctions in context of administrative law. By using the administrative sanction such as paying the tax due or underpaid tax along with the fines, then the taxpayer obligation has been fulfilled. Besides, there are another instruments that can be used to force taxpayer in order to pay tax by way of confiscation of taxpayer's property that can be proceed on auction of confiscated taxpayer's property, which is regulated in Law Number 19 of 2000 on the Tax Collection by Giving Forced Letter. The imposition of criminal sanctions perceived to be ineffective because it would burden the country with the need to provide a place/building along with the living cost of the taxpayer during their period of detention.

Besides, the criminal sanctions implemented to the taxpayer is not remove their tax due. Even if the taxpayer is imprisoned or being in confinement, towards

14 Wirjono Prodjodikoro, 2003, Asas-Asas Hukum Pidana di Indonesia, Refika Aditama, Bandung, p. 17. 
the obligation of taxpayer to pay the tax due still exists. Similar to the law enforcement without trial that ever conducted in 1964 and 1984 through the "Tax Amnesty" policy. Based on the policy of tax amnesty stipulated in Presidential Decree Number 15 of 1964 and the Presidential Decree Number 26 of 1984, the taxpayers that used these instruments be exempted from the fiscal investigation and their wealth report were not used as the basis of investigation and criminal prosecution of any kind with the terms of taxpayers compensation to pay their tax due amounted to a certain percentage of tax due that should be paid. Likewise, the Taxation General Provisions and Procedures Law 2007, through Article 37A provides opportunities for taxpayers to get tax amnesty, which is referred to as a sunset policy.

Policy of criminalization towards certain acts, according Sudarto ${ }^{15}$ among others, must consider the principles of "cost

\section{Conclusion}

Based on the discussion, it can be concluded as follows: First, the payment of principal tax due along with an administrative fine that is about to 4 (four) times of the amount of unpaid tax due or underpaid tax due, does not eliminate the unlawful nature of the taxpayer. Acts committed by the taxpayer is still recognized as an act against the law. Thus, it means that the taxpayer acts remain categorized as acts contrary to the taxation law. In other words, the principal taxes and fines payment are not being a justifiable act. The payment of the tax due as well as the administrative sanctions as defined in Article 44B Taxation General Provisions and Procedures Law doesn't lead to the abolishment of criminal acts from the taxpayer. The termination of investigation from the Attorney General towards several criminal cases in taxation cause the investigation of the criminal cases of tax stops. Termination of investigation by the Attorney and outcome" (cost-benefit principle) and the capacity and ability of the law enforcement agencies, so that it will not exceed burden of the law enforcement agencies' (overbelasting).

The imposition of criminal sanctions for taxpayer is not more favourable than the imposition of administrative sanctions, since the imposition of criminal sanctions either imprisonmentor confinement will notgenerate revenues, on the contrary it will increase the burden on the state. This is understandable considering the harmful elements of the national income from tax sector to be removed by the tax due repayments along with the administrative sanctions. In other words, the tax due repayment along with the administrative sanctions may successfully save the state due to the tax revenue which gives large contribution to national income has been fulfilled.

General made by the reason of the sake of state revenue.

Second, termination of the investigation that caused by payments of principal tax due and its fines from the taxpayer does not mean that Article 44B Taxation General Provisions and Procedures Law adheres non penal law enforcement. During the law enforcement through a process or mechanism, inquiry, investigation and prosecution where is applicable under provisions of Criminal Code, so that the law enforcement under Article 44B Taxation General Provisions and Procedures Law is still categorized as a law enforcement through judicial mechanisms that will take quite long time. For the sake of state revenue, as long as the taxpayer do not commit criminal acts out of the criminal tax, it can be used the existing administration sanctions without any further investigation as a model of law enforcement in the field of taxation without going through the litigation process.

15 Sudarto, 2006, Kapita Selekta Hukum Pidana, Alumni, Bandung, p. 62. 


\section{BIBLIOGRAPHY}

\section{A. Books}

Ali, Mahrus, 2011, Dasar-Dasar Hukum Pidana, Sinar Grafika, Jakarta.

Farid, Andi Zaenal Abiding, 2007, Hukum Pidana I, Sinar Grafika, Jakarta.

Moeljatno, 2008, Asas-Asas Hukum Pidana, Rineka Cipta, Jakarta.

Saleh, Roeslan, 1987, Sifat Melawan Hukum dari Perbuatan Pidana, Aksara Baru, Jakarta.

Sapardjaja, Komariah Emong, 2013, Ajaran Sifat Melawan Hukum Materiil dalam Hukum Pidana Indonesia, Studi Kasus tentang Penerapan dan Perkembangannya dalam Yurisprudensi, Alumni, Bandung.

Soemitro, Rochmat, 1991, Asas dan Dasar Perpajakan 3, Eresco, Bandung. , 2008, Pajak Ditinjau dari Segi Hukum, Eresco, Bandung.

Sudarto, 2006, Kapita Selekta Hukum Pidana, Alumni, Bandung.

Suparman, 1994, Tindak Pidana di Bidang Perpajakan, Citra Aditya Bakti, Bandung.

Tongat, 2008, Dasar-Dasar Hukum Pidana Indonesia dalam Perspektif Pembaharuan, UMM Press, Malang.

Tresna, 2007, Komentar HIR, Pradaya Paramita, Jakarta.

Wirjono Prodjodikoro, 2003, Asas-Asas Hukum Pidana di Indonesia, Eresco Bandung.

\section{B. Regulations}

Criminal Code of Indonesia.

Law Number 8 of 1981 concerning Code of Criminal Procedure (State Gazette of the Republic of Indonesia Year 1982 Number 76, Supplement to State Gazette of the Republic of Indonesia Number 3209).

Law Number 19 of 2000 concerning Amendmend of Law Number 19 of 1997 concerning Tax Collection By Giving Forced Letter (State Gazette of the Republic of Indonesia Year
2000 Number 159, Supplement to State Gazette of the Republic of Indonesia Number 3987).

Law Number 14 of 2002 concerning Tax Court (State Gazette of the Republic of Indonesia Year 2002 Number 27, Supplement to State Gazette of the Republic of Indonesia Number 4189).

Law Number 17 of 2003 concerning Public Finance (State Gazette of the Republic of Indonesia Year 2003 Number 47, Supplement to State Gazette of the Republic of Indonesia Number 4286).

Law Number 6 of 1983 concerning Taxation General Provisions and Procedures as last amended by Law Number 16 of 2009 (State Gazette of the Republic of Indonesia Year 2009 Number 62, Supplement to State Gazette of the Republic of Indonesia Number 4999).

Regulation of the Minister of Finance of the Republic of Indonesia Number 199/PMK.03/2007 as last amended by Regulation of the Minister of Finance of the Republic of Indonesia Number 82/PMK.03/2011 concerning Procedure of Tax Audit.

\section{Internet Articles}

Mahatma, Yudhi, "Menkeu Optimistis Target Penerimaan Pajak 2013 Tercapai", http://www. republika.co.id, accessed on 25 March 2014.

Ministry of Tax of the Republic of Indonesia, "Penerimaan Negara Detil 2009", http:// www.pajak.go.id/content/penerimaannegara-detil-2009-2012, accessed on 25 March 2014.

Atmasasmita, Romli, “TindakPidana diBidang Pajak dan Tipikor", http://nasional.sindonews.com/ read/926225/18/tindak-pidana-di-bidangpajak-dan-tipikor-1416330000, accessed on 24 November 2014. 